\title{
Effect of Insulin on Amino Acid Transport in Isolated Rat Hepatocytes
}

\author{
A. Le Cam and P. Freychet \\ Institut National de la Sante̋ et de la Recherche Médicale (I.N.S.E.R.M.) U 145, Nice, France
}

\begin{abstract}
Summary. The effects of insulin on amino acid transport were studied in freshly prepared suspensions of isolated hepatocytes from adult rats. Insulin stimulated the active transport of $\alpha$-aminoisobutyric acid by increasing the influx. The onset of the insulin effect was delayed by thirty to sixty min. Insulin increased the Vmax of transport by about $60 \%$ without affecting the $\mathrm{Km}$. Cycloheximide and actinomycin D inhibited hormonal action by 60 to $80 \%$. Only the " $\mathrm{A}$ " system of transport was affected by insulin. Half-maximal stimulation of transport was observed with insulin at 2 to $3 \mathrm{nmol} / \mathrm{l}$, a concentration which also occupies about $50 \%$ of insulin-specific binding sites at steady state. Insulin did not antagonize the stimulatory effect of glucagon on amino acid transport.
\end{abstract}

Key words: Amino acid transport, isolated hepatocytes, liver, insulin action, insulin binding.

The hormonal regulation of amino acid transport is of particular physiological importance in eukaryotic cells. Thus, insulin has been shown to enhance the accumulation of amino acids in skeletal and cardiac muscle, bone, lymphoid cells, mammary epithelial cells and hepatoma culture cells (see Ref. 1 for review). Insulin has also been reported to stimulate the uptake of $\alpha$-aminoisobutyric acid by the isolated perfused rat liver [2] and more recently to induce amino acid transport in freshly isolated rat hepatocytes [3] and in primary cultures of adult rat liver parenchymal cells [4]. We have previously characterized the transport systems that are operative for neutral amino acids in freshly isolated hepatocytes from the adult rat [5]. We have also demonstrated that glucagon [6, 7], catecholamines [8] and glucocorticoids [9] stimulate amino acid transport in the hepatocyte by specifically increasing the activity of the A system of transport.

The present studies were designed to investigate the effect of insulin on amino acid transport in isolated hepatocytes in more detail. Several aspects of insulin effect on transport have been analyzed and the relationship between insulin binding and insulin action on amino acid transport has been examined.

\section{Materials and Methods}

Isolated hepatocytes were prepared from 6 to 8 week-old male Wistar rats following the procedure previously described [10]. The animals were maintained in a constant temperature $\left(23^{\circ} \mathrm{C}\right)$ animal room with a fixed $12 \mathrm{~h}$ light $-12 \mathrm{~h}$ dark cycle (the light period starting at $8 \mathrm{a} . \mathrm{m}$.), and had free access to laboratory chow containing $21 \%$ protein, $4 \%$ fat and $51 \%$ carbohydrate until the time of sacrifice (9-11 a.m.). Freshly prepared hepatocytes have been shown to retain well preserved ultrastructure [10], metabolic capabilities [10] and active transport systems for amino acids [5]. The intracellular levels of ATP (15 to $20 \mathrm{nmol} / 10^{6}$ cells) and $\mathrm{K}^{+}$ (130 to $150 \mathrm{mmol} / 1$ of cell water) remained stable for periods of $3 \mathrm{~h}$ at $37^{\circ} \mathrm{C}$ following cell isolation. All experiments were carried out at $37^{\circ} \mathrm{C}$ in Krebs-Ringer bicarbonate buffer containing bovine serum albumin fraction $V(10 \mathrm{mg} / \mathrm{ml})$, gentamycin $(50 \mu \mathrm{g} / \mathrm{ml})$ and bacitracin $(1 \mathrm{mg} / \mathrm{ml})$, and gassed with $\mathrm{O} 2: \mathrm{CO}_{2}(95: 5, \mathrm{~V} / \mathrm{V})$. Cells at about $1.5 \times 10^{6} / \mathrm{ml}$ were incubated with various agents for the times indicated; they were then washed twice with fresh buffer before the addition of a mixture of labelled and unlabelled amino acid as indicated in the legends to figures. The analytical procedure employed to measure transport and the mode of expression of the results have previously been described $[5,6]$.

Studies of insulin binding to hepatocytes were performed under the same experimental conditions of buffer, temperature, and cell concentration as those used in transport experiments. ${ }^{125} \mathrm{I}$ insulin (specific activity $\approx 300 \mu \mathrm{Ci} / \mu \mathrm{g}$ ) was iodinated as described elsewhere [11] and exhibited receptor-binding ability that was similar to that of mono ${ }^{125}$ I-insulin [12] obtained after DEAEcellulose chromatography (data not shown). The specific binding of ${ }^{125} \mathrm{I}$-insulin $(0.5 \mathrm{ng} / \mathrm{ml}, 0.08 \mathrm{nmol} / \mathrm{l})$ was determined after 20 


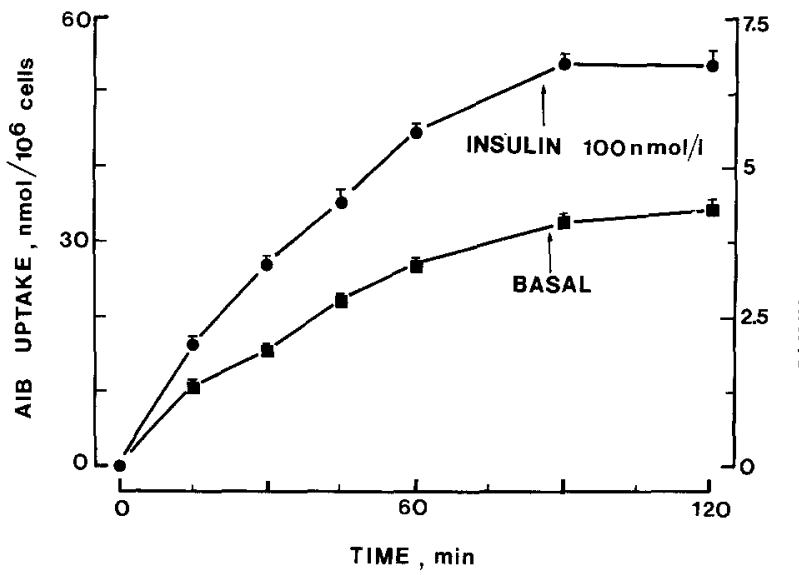

Fig. 1. Effect of insulin on the time course of AIB uptake. Suspensions of hepatocytes were preincubated for $2 \mathrm{~h}$ in the absence (basal) or presence of insulin. The uptake of $2 \mathrm{mmol} / 1\left[{ }^{14} \mathrm{C}\right] \mathrm{AIB}$ was then measured at the times indicated. The distribution ratio was calculated by dividing the intracellular concentration of AIB by the extracellular concentration; intracellular water $\left(\approx 4 \mu 1 / 10^{6}\right.$ cells) was determined in the same cell preparation. Each point is the mean $\pm S E M$ of four determinations

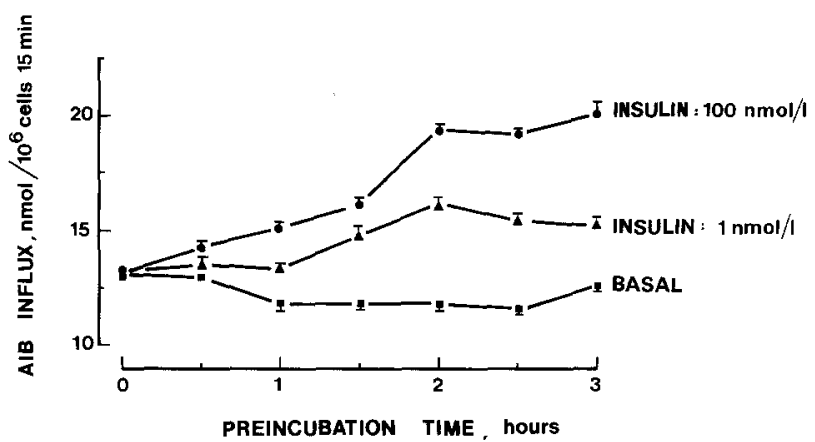

Fig. 2. Effect of duration of cell pre-exposure to insulin on AIB influx. Suspensions of hepatocytes were incubated in the absence or presence of insulin. At the times indicated, initial rates of transport were measured by incubating aliquot samples with $2 \mathrm{mmol} / \mathrm{l}$ $\left[{ }^{14} \mathrm{C}\right] \mathrm{AIB}$ for $15 \mathrm{~min}$. Each value is the mean $\pm \mathrm{SEM}$ of four determinations. Time 0 on figure represents a $15 \mathrm{~min}$ exposure of hepatocytes to insulin since the hormone was present during the transport assay

min incubation at $37^{\circ} \mathrm{C}$, a period which achieves apparent steady state of binding at this temperature [13]. At the end of incubation $300 \mu \mathrm{l}$-samples were rapidly transferred to plastic tubes containing chilled buffer. Cells were sedimented by centrifugation and washed once with chilled buffer. Non-specific binding was estimated by measuring cell-bound radioactivity in the presence of a large excess $(50$ to $100 \mu \mathrm{g} / \mathrm{ml}$ ) of unlabelled insulin. The nonspecific component of binding did not exceed 10 to $15 \%$ of total binding.

Glucose was assayed in the incubation medium by the glucose oxidase method [14].

Porcine monocomponent insulin and glucagon were gifts from J. Schlichtkrull (Novo Research Institute, Copenhagen, Denmark) and G. Jouve (Novo Paris, France). $\alpha$-Aminoisobutyric acid

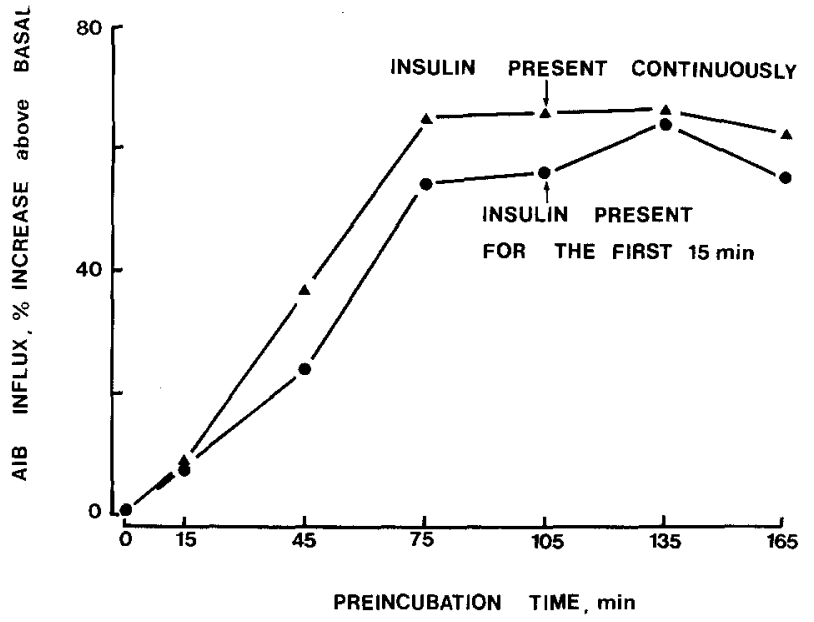

Fig. 3. Persistence of insulin effect after insulin withdrawal. Hepatocytes were incubated in the absence or presence of $100 \mathrm{nmol} / 1$ insulin. After $15 \mathrm{~min}$ of cell exposure to the hormone, hepatocytes were isolated by centrifugation, washed twice with buffer, and resuspended in insulin-containing medium ("insulin present continuously") or insulin-free medium ("insulin present for the first $15 \mathrm{~min}^{\prime}$ ) for the times indicated. The influx of $\left[{ }^{14} \mathrm{C}\right] \mathrm{AIB}(2 \mathrm{mmol} / \mathrm{l})$ was then measured over $15 \mathrm{~min}$. Each point is the mean of four determinations

(AIB), aminocyclopentane carboxylic acid (cycloleucine), cycloheximide, gentamycin and bacitracin were purchased from Sigma. Actinomycin D and the glucose oxidase kit were from Boehringer Co.

The amino acid analogue $\alpha$-(methylamino)-isobutyric acid (N-methyl AIB) was a gift from H.N. Christensen (Ann Arbor, Michigan); $\alpha$-amino $\left[1-{ }^{14} \mathrm{C}\right]$ isobutyric acid and l-aminocyclopentane $\left[1-{ }^{14} \mathrm{C}\right]$ carboxylic acid were purchased from the Radiochemical Centre (Amersham, England).

\section{Results}

\section{Effect of Insulin on the Time Course of AIB Uptake}

Insulin at $100 \mathrm{nmol} / 1$ increased both the initial rate and the steady state level of AIB transport in isolated hepatocytes (Fig. 1). In cells previously exposed to insulin, the distribution ratio was increased by 50 to $60 \%$. The extent of increase observed at each time point was similar, suggesting that the hormone effect was to enhance the influx without altering the efflux. The fractional efflux of AIB from cells exposed to insulin was indeed indistinguishable from that observed with control cells (not shown).

\section{Dependence of Stimulation of AIB Transport on the Duration of Cell Exposure to Insulin}

The stimulatory effect of insulin on AIB uptake did not occur instantaneously. When cells were incubated with or without insulin for various lengths of 


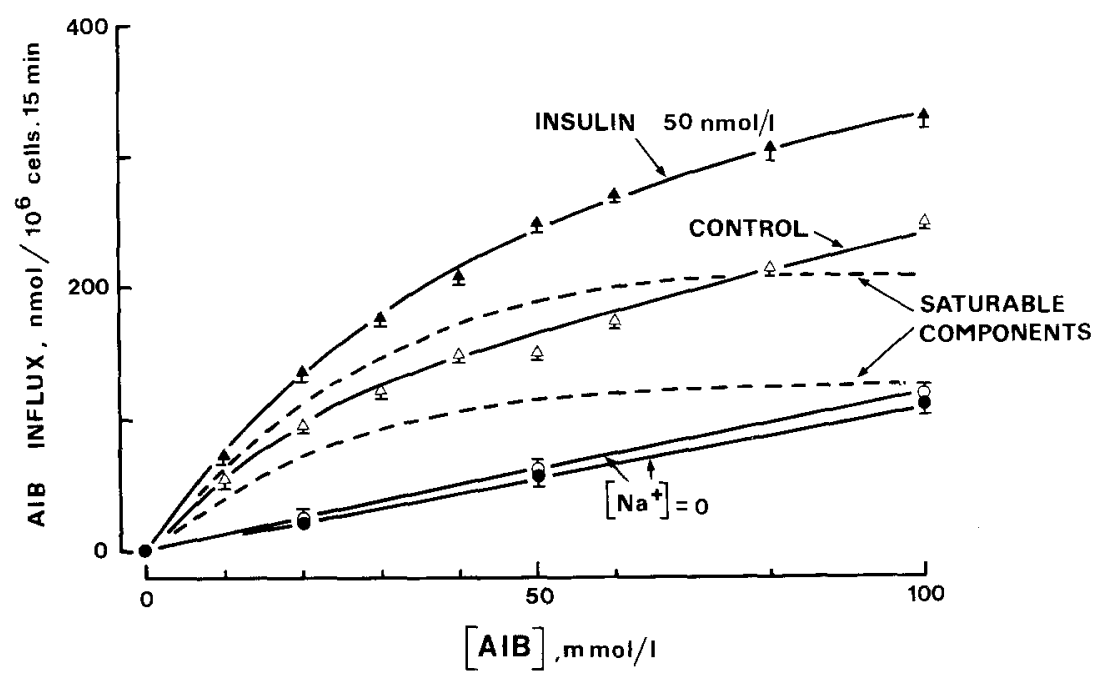

Fig. 4. Effect of insulin on kinetic parameters of AIB transport. Hepatocytes were preincubated for $2 \mathrm{~h}$ in a sodium-containing medium and in the absence $(\triangle-\triangle$ and $O-O)$ or presence of insulin ( $\Delta-\Delta$ and $-\infty)$. Initial rates of transport were then measured for the external AIB concentrations indicated. Sodium was replaced by choline when a sodium-free medium was required during transport assay. Closed symbols represent insulin-treated cells $(\mathbf{\Lambda}-\mathbf{\Lambda}$ : sodium present during transport assay; $-\mathbf{-}$ : sodium absent during transport assay); open symbols represent control cells $(\triangle-\triangle$ : sodium present during transport assay; $O-0$ : sodium absent during transport assay). The upper and lower dotted lines represent the saturable components of transport. This was calculated for insulin-treated and control cells, respectively, by subtracting from total the transport measured in the absence of sodium, $\left(\left[\mathrm{Na}^{+}\right]=0\right)$. Each point is the mean $\pm \mathrm{SEM}$ of four determinations

time prior to the addition of $\left[{ }^{14} \mathrm{C}\right] \mathrm{AIB}$, the hormone effect became significant only after $30 \mathrm{~min}$ of preincubation, to reach a maximum by $2 \mathrm{~h}$ (Fig. 2). The continuous presence of insulin was, however, not required since the stimulatory effect was of similar degree in hepatocytes permanently exposed to the hormone and in cells exposed to insulin for only the first $15 \mathrm{~min}$ of the preincubation period (Fig. 3).

\section{Effect of Inhibitors of RNA and Protein Synthesis on Basal and Insulin-Stimulated AIB Transport}

Actinomycin D at $1 \mu \mathrm{g} / \mathrm{ml}(0.8 \mu \mathrm{mol} / \mathrm{l})$ and cycloheximide at $0.1 \mathrm{mmol} / \mathrm{l}$ inhibited the insulin stimulation of transport by 60 to $80 \%$, without significantly altering the basal (i.e., non-insulin-stimulated) uptake of AIB (Table 1). Under the same conditions, actinomycin D inhibited RNA synthesis and protein synthesis by $95 \%$ and $40 \%$, respectively, and cycloheximide inhibited protein synthesis by $90 \%$ (not presented).

\section{Effect of Insulin on the Kinetic Parameters of $A I B$ Transport}

Insulin did not influence the non-saturable, sodiumindependent component of AIB transport (Fig. 4). The Vmax of the saturable, sodium-dependent component of transport $\left(\approx 130 \mathrm{nmol} / 10^{6}\right.$ cells. $\left.15 \mathrm{~min}\right)$ was increased by insulin $\left(\approx 210 \mathrm{nmol} / 10^{6}\right.$ cells. 15
Table 1. Effect of cycloheximide and actinomycin D on basal and insulin-stimulated AIB influx

\begin{tabular}{|c|c|c|c|}
\hline \multirow[t]{2}{*}{ Inhibitor } & \multicolumn{3}{|l|}{ Insulin } \\
\hline & 0 & $1 \mathrm{nmol} / 1$ & $100 \mathrm{nmol} / 1$ \\
\hline & \multicolumn{3}{|c|}{ AIB influx: nmol $/ 10^{6}$ cells. $15 \mathrm{~min}$} \\
\hline $\begin{array}{l}\text { None } \\
\text { Cycloheximide }\end{array}$ & $18.5 \pm 0.6$ & $27.5 \pm 0.3$ & $33.0 \pm 0.6$ \\
\hline $\begin{array}{l}0.1 \mathrm{mmol} / 1 \\
\text { Actinomycin } \mathrm{D}\end{array}$ & $16.5 \pm 0.4$ & $17.7 \pm 0.3$ & $21.8 \pm 0.3$ \\
\hline $1 \mu \mathrm{g} / \mathrm{ml}$ & $16.0 \pm 0.6$ & $19.3 \pm 0.4$ & $21.4 \pm 0.6$ \\
\hline
\end{tabular}

Hepatocytes were incubated for $30 \mathrm{~min}$ in the absence or presence of cycloheximide or actinomycin $\mathrm{D}$ prior to addition of insulin. Incubations were continued for $2 \mathrm{~h} .\left[{ }^{14} \mathrm{C}\right] \mathrm{AIB}$ influx $(2 \mathrm{mmol} / \mathrm{l})$ was then measured. Each value is the mean \pm SEM of four determinations

$\mathrm{min})$, whereas the apparent $\mathrm{Km}$ remained essentially unaltered $(\approx 20 \mathrm{mmol} / \mathrm{l})$ (Fig. 4).

\section{Effect of Insulin on Transport Systems}

The saturable, sodium-dependent transport of AIB in the hepatocyte occurs through the A ("Alanine" preferring) and ASC ("Alanine, Serine, Cysteine") systems [5]. When the influx of AIB was measured in a sodium-containing medium and in the presence of an excess of $\mathrm{N}$-methyl AIB, conditions under which the entry of AIB through the A system is largely 


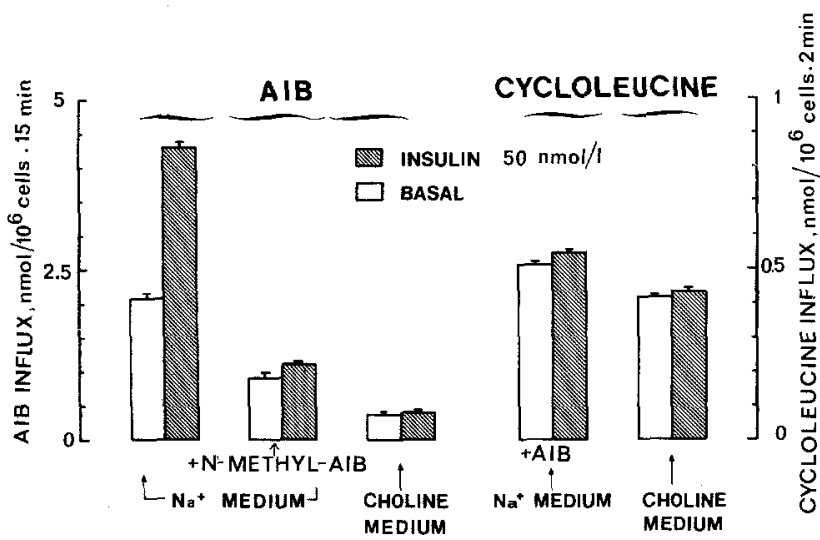

Fig. 5. Effect of insulin on amino acid transport systems. Cells were preincubated for $2 \mathrm{~h}$ without (basal) or with insulin $(50 \mathrm{nmol} /$ 1), in a sodium-containing medium. After washing twice, cells were resuspended in buffer without or with sodium and without or with insulin. AIB $(0.25 \mathrm{mmol} / \mathrm{l})$ influx was then measured in the absence or presence of $10 \mathrm{mmol} / 1 \mathrm{~N}$-methyl-AIB. Cycloleucine $(0.2 \mathrm{mmol} / \mathrm{l})$ influx was measured in sodium-free medium or in sodium-containing medium in the presence of $30 \mathrm{mmol} / \mathrm{l}$ AIB. Each value represents the mean \pm SEM of six determinations

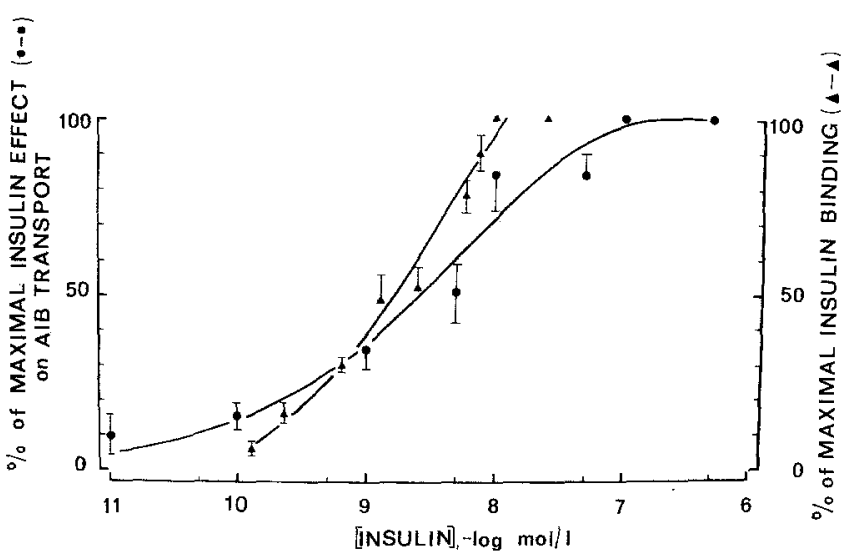

Fig. 6. Dose response curves for insulin binding and insulin stimulation of AIB transport. Hepatocytes were preincubated for $2 \mathrm{~h}$ in the presence of varying concentrations of insulin before the addition of $2 \mathrm{mmol} / 1$ [ $\left.{ }^{14} \mathrm{C}\right] \mathrm{AIB}$. Amino acid influx (-) was then measured after $15 \mathrm{~min}$. The results are expressed as percent of maximal insulin effect obtained at $100 \mathrm{nmol} / 1$ and represent the mean \pm SEM of four separate experiments. The binding of insulin to hepatocytes (using ${ }^{125} I$-insulin and increasing concentrations of unlabelled insulin) was measured at steady state after $20 \mathrm{~min}$ incubation under conditions (buffer, temperature, cell concentration) similar to those employed in transport experiments. Binding $(\boldsymbol{\Delta}-\boldsymbol{\Delta})$ is expressed as percent of maximal binding taken as the amount of hormone specifically bound at $10 \mathrm{nmol} / \mathrm{insulin}$, a concentration at which the specific binding of insulin is virtually saturated under the experimental conditions employed. Each point represents the mean \pm SEM of three separate experiments inhibited, the stimulatory effect of insulin was no longer observed; insulin was also without effect on the sodium-independent entry (physical diffusion) of AIB, measured in a choline medium (Fig. 5). Thus, insulin specifically increases the activity of transport system A.

The saturable transport of cycloleucine in hepatocytes occurs through the L ("Leucine" preferring) system (sodium-independent) for about $80 \%$ and through the A and ASC systems for 20\% [5]. Two conditions allow for the measurement of cycloleucine transport through system L: the saturation of systems A and ASC by an excess of AIB, or the use of a sodium-free (choline) medium. Under both conditions, insulin did not significantly affect the transport of cycloleucine (Fig. 5), therefore excluding an effect of the hormone on the $\mathrm{L}$ system of transport.

\section{Dose Response of Insulin Stimulation of AIB Influx; Comparison with Insulin Binding}

The stimulatory effect of insulin on AIB transport could be detected with hormone concentrations as low as $0.1 \mathrm{nmol} / 1(0.6 \mathrm{ng} / \mathrm{ml}$ or $15 \mu \mathrm{U} / \mathrm{ml})$; the apparent half-maximal stimulation (Effective Dose 50, $\mathrm{ED}_{50}$ ) occurred at 2 to $3 \mathrm{nmol} / \mathrm{l}$ insulin, and maximal effect was achieved with 50 to $100 \mathrm{nmol} / \mathrm{l}$ (Fig. 6). When the binding of insulin to hepatocytes was measured at steady state (after $20 \mathrm{~min}$ at $37^{\circ} \mathrm{C}$ ), the apparent value for half-maximal receptor occupancy was 1 to $2 \mathrm{nmol} / 1$ insulin (Fig. 6). Therefore, the apparent $\mathrm{ED}_{50}$ for insulin-stimulated AIB transport and the apparent insulin concentration for half-maximal receptor occupancy appear to be very similar. Despite the different time dependence of both processes, such comparison between insulin binding at steady state and subsequent effect on amino acid transport seems to be warranted by the observation that the continuous presence of insulin is not required (beyond $15 \mathrm{~min}$ of cell exposure to the hormone) for the subsequent generation of stimulation of amino acid transport (Fig. 3). The dose dependence relationships for insulin binding and subsequent effect on amino acid transport could have been affected by the degradation of insulin in the medium during its exposure to hepatocytes; however, under the conditions used (after $15 \mathrm{~min}$ incubation at $37^{\circ} \mathrm{C}$ in the presence of bacitracin), the degradation did not exceed $20 \%$ with insulin at $100 \mathrm{nmol} / 1$ and $26 \%$ with insulin at $0.1 \mathrm{nmol} / \mathrm{l}$.

\section{Combined Effects of Insulin and Glucagon on Glycogenolysis and AIB Transport}

Insulin largely inhibited the glucagon-stimulated glycogenolysis in isolated hepatocytes, without signifi- 
cantly affecting the basal rate of glycogenolysis (Fig. 7, left). Since there was a good quantitative agreement between the disappearance of cell glycogen and the release of glucose into the medium (unpublished observations), it is likely that gluconeogenesis contributed very little of the glucose output. In the same cell suspension, both insulin and glucagon enhanced AIB transport; in contrast to their action on glycogenolysis, the two hormones exerted no antagonistic effect on the transport of AIB measured after 2 hours of cell exposure to the hormones (Fig. 7, right) used in combination at maximally effective concentrations (10nmol/1 glucagon and $100 \mathrm{nmol} / 1$ insulin).

\section{Discussion}

The present study has provided evidence that insulin, at concentrations within the physiological values in hepatic portal blood, stimulates directly the concentrative uptake of AIB in suspensions of freshly isolated hepatocytes from the adult rat. These observations confirm and extend previous reports on insulin effect on AIB uptake in the isolated perfused rat liver [2], in primary cultures of adult rat liver parenchymal cells [4], and in isolated hepatocytes [3].

The use of isolated hepatocytes has made it possible to analyze the effects of insulin in kinetic and quantitative terms. The stimulatory effect of insulin on amino acid transport in hepatocytes shares many characteristics with that elicited by other hormones. Thus, as previously observed with glucagon $[6,7]$, catecholamines [8] and glucocorticoids [9], the stimulatory effect of insulin was restricted to system $\mathrm{A}$, the sodium-dependent, active and concentrative transport system for neutral amino acids $[1,5]$. This is in keeping with the observation that the A mediation of amino acid transport is the sole system subject to regulation (both hormonal and non-hormonal) in a variety of cells [1], and stresses the physiological importance of this system. As also observed with glucagon [6,7], catecholamines [8] and glucocorticoids [9], the stimulation of amino acid transport by insulin was dependent on new protein synthesis, since it was largely suppressed under conditions where protein synthesis was virtually abolished (cycloheximide) or substantially depressed (actinomycin D). Although it is clear that new protein synthesis is implicated in the effect of insulin on amino acid transport in hepatocytes, attempts to discriminate between a possible effect of insulin at the transcriptional level and its effect at the translational level [15] have not been conclusive (not presented). Along with the lag period observed (about $30 \mathrm{~min}$ ) before

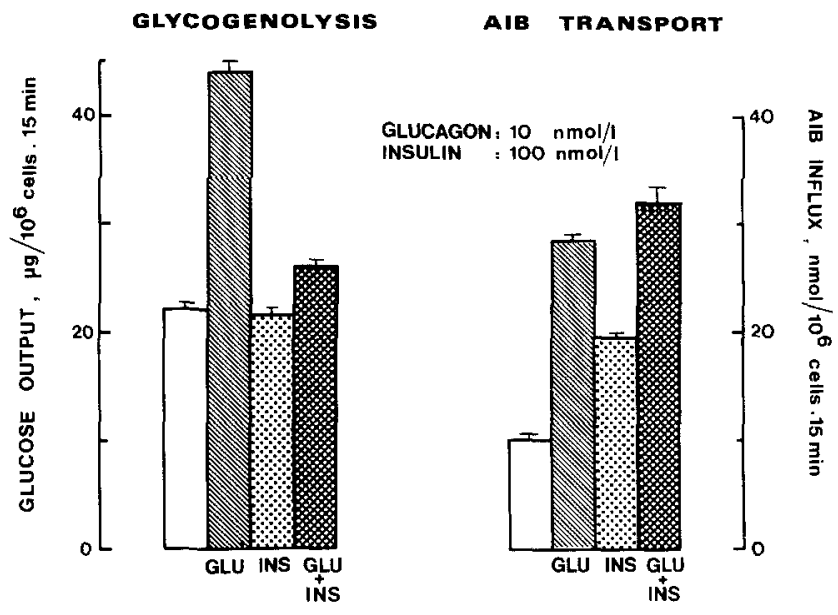

Fig. 7. Effect of insulin and glucagon on glycogenolysis and AIB transport. Hepatocytes were preincubated in the absence or presence of each hormone used alone or combined. Glycogenolysis was evaluated by measuring the glucose release in the incubation medium after $15 \mathrm{~min}$. The influx of $\left[{ }^{14} \mathrm{C}\right] \mathrm{AIB}(2 \mathrm{mmol} / \mathrm{l})$ was measured over $15 \mathrm{~min}$ in cells previously exposed to hormones for $2 \mathrm{~h}$. Each bar is the mean \pm SEM of four determinations

the onset of insulin action, and with the increase in the Vmax of transport elicited by the hormone, the results suggest that insulin enhances amino acid transport by inducing the new synthesis of carrier proteins. This is similar to the characteristics of insulin's effect on amino acid transport in primary cultures of hepatocytes [4] and in a number of other tissue and cell types [1].

Comparisons between the binding of insulin to its receptors and subsequent biological effects of the hormone have generally revealed complex relationships [16]. In the present study, such comparison has been further complicated by the fact that insulin binding and effect on amino acid transport appear to be rather distant processes, both temporally and sequentially, since a number of events (e. g., new protein synthesis) supervene between hormone binding and expression of biological effect. It was observed however that, after hepatocytes had been exposed to insulin for $15 \mathrm{~min}$ at $37^{\circ} \mathrm{C}$ (a time sufficient to achieve steady state binding of the hormone), the continuous presence of insulin in the incubation medium was no longer required to observe the subsequent stimulation of transport (Fig. 3). Also, under these conditions (resuspension of hepatocytes in insulin-free medium following exposure to ${ }^{125} \mathrm{I}$-insulin for $20 \mathrm{~min}$ at $37^{\circ} \mathrm{C}$ ), $70 \%$ and $80 \%$ of cell-associated radioactivity is released from hepatocytes after 60 and $120 \mathrm{~min}$, respectively (unpublished results). It thus appears that, once insulin has bound to receptors, a signal is generated which does not depend on the continuous presence of the hormone in the extra- 
cellular medium or on a cellular site accessible to dissociation. It therefore seems valid to compare the dose-response relationships of insulin binding at steady state and subsequent effect on amino acid transport. Such comparison has revealed that the stimulation of amino acid transport by insulin bears some proportional relationship to the occupancy of receptor sites by the hormone throughout the whole range of dose-response curves. Similar results have been reported in comparing insulin binding and effect on amino acid transport in rat thymocytes [17, 18]. This is in contrast to the relationship between insulin binding and effects in rat adipocytes [19-21] and in mouse skeletal muscle [22]; in these systems, maximal insulin effects on glucose transport and metabolism are achieved when only a fraction of total receptors is occupied by the hormone [19-22]. Whether this apparent discrepancy in insulin action implicates the generation of different signal(s) and/or represents a distinctive feature of the long term "trophic" (and possible growth-promoting) effects of the hormone, as opposed to its rapid metabolic effects, is unknown at present.

Finally, the physiological implications of these findings deserve mention. Since insulin and glucagon usually exert opposite actions on liver metabolism, it is remarkable that both promote amino acid transport in the liver (Fig. 7). The rise in both insulin and glucagon secretion following a protein meal or amino acid administration is also a rather unique physiological situation where the secretions of $A$ and $B$ cells change in the same direction. Thus, the teleology of the rise in glucagon secretion in response to protein ingestion, i. e., to prevent hypoglycaemia as a consequence of aminogenic insulin secretion [23] appears to have a corollary in the concerted action of both hormones to increase amino acid transport in the liver. That glucagon exerts a faster effect than insulin on this variable [7] may be consistent with the need for a rapid activation of gluconeogenesis (a concomitant of the acute metabolic effects of insulin on glucose storage in the liver and utilization at the periphery), thus permitting subsequent stimulation by insulin of anticatabolic and - or - anabolic processes through sustained entry of amino acids in the liver.

Acknowledgements. We thank G. Le Cam and G. Visciano for skilful technical assistance and J. Duch for excellent secretarial assistance.

This work was supported by grants 75.7.1366 and 77.7.0247 from the Délégation Générale à la Recherche Scientifique et Technique and by the Fondation pour la Recherche Médicale Française.

\section{References}

1. Guidotti, G. G., Borghetti, A. F., Gazzola, G. C., Tramacere, M. R., Dall'Asta, V.: Insulin regulation of amino acid transport in mesenchymal cells from avian and mammalian tissues. Biochem. J. 160, 281-286 (1976)

2. Chambers, J.W., Georg, R. H., Bass, A. D.: Effect of hydrocortisone and insulin on uptake of $\alpha$-aminoisobutyric acid by isolated perfused rat liver. Mol. Pharmacol. 1, 66-76 (1965)

3. Jefferson, L. S.: Stimulation by insulin and glucagon of $\alpha$ aminoisobutyric acid uptake in isolated hepatocytes (Abstract 31). Fed. Proc. 213 (1976)

4. Kletzien, R. F., Pariza, M. N., Becker, J. E., Potter, V. R., Butcher, F. R.: Induction of amino acid transport in primary cultures of adult rat liver parenchymal cells by insulin. J. Biol. Chem. 251, 3014-3020 (1976)

5. Le Cam, A., Freychet, P.: Neutral amino acid transport. Characterization of the $A$ and $L$ systems in isolated rat hepatocytes. J. Biol. Chem. 252, 148-156 (1977)

6. Le Cam, A., Freychet, P.: Glucagon stimulates the A system for neutral amino acid transport in isolated hepatocytes of adult rat. Biochem. Biophys. Res. Commun. 72, 893-901 (1976)

7. Freychet, P., Le Cam, A.: Amino acid transport in isolated hepatocytes: effect of glucagon. In hepatotrophic factors, Proceedings of the Ciba Foundation. Excerpta Med. 55, 247-268 (1978)

8. Le Cam, A., Freychet, P.: Effect of catecholamines on amino acid transport in isolated rat hepatocytes. Endocrinology 102, 379-385 (1978)

9. Le Cam, A., Freychet, P.: Effect of glucocorticoids on amino acid transport in isolated rat hepatocytes. Mol. Cell. Endocrinol. 9, 205-214 (1977)

10. Le Cam, A., Guillouzo, A., Freychet, P.: Ultrastructural and biochemical studies of isolated adult rat hepatocytes prepared under hypoxic conditions. Cryopreservation of hepatocytes, Exp. Cell Res. 98, 382-395 (1976)

11. Maldonato, A., Trueheart, P. A., Renold, A. E., Sharp, G.W. G.: Effects of streptozotocin in vitro on proinsulin biosynthesis, insulin release and ATP content of isolated rat islets of Langerhans. Diabetologia 12, 471-481 (1976)

12. Freychet, P.: Insulin receptors. In: M. Blecher (Ed.): Methods in Receptor Research, Part II, pp 385-428. New York and Basel: Marcel Dekker, Inc. 1976

13. Freychet, P., Rosselin, G., Rançon, F., Fouchereau, M., Broer, Y.: Interactions of insulin and glucagon with isolated rat liver cells. I. Binding of the hormones to specific receptors. Horm. Metab. Res. [Suppl. Series] 5, 72-78 (1974)

14. Bergmeyer, H. U., Bernt, E.: Glukose Bestimmung mit Glukose-Oxydase und Peroxydase. In: H. U. Bergmeyer (Ed.): Methoden der Enzymatischen Analyse, 3rd edit., pp. 1250-1257. Weinheim: Verlag Chemie 1974

15. Guidotti, G. G., Franchi-Gazzola, R., Gazzola, G. C., Ronchi, P.: Regulation of amino acid transport in chick embryo heart cells. IV. Site and mechanism of insulin action. Biochim. Biophys. Acta 356, 219-230 (1974)

16.Freychet, P.: Interactions of polypeptide hormones with cell membrane specific receptors: studies with insulin and glucagon. Diabetologia 12, 83-100 (1976)

17. Goldfine, I. D., Gardner, J. D., Neville, D. M.: Insulin action in isolated rat thymocytes. I. Binding of ${ }^{125} \mathrm{I}$-insulin and stimulation of $\alpha$-aminoisobutyric acid transport. J. Biol. Chem. 247, 6919-6926 (1972) 
18. Goldfine, I. D.: Binding of insulin to thymocytes from suckling and hypophysectomized rats: Evidence for two mechanisms regulating insulin sensitivity. Endocrinology 97, 948-954 (1975)

19. Kono, T., Barham, F. N.: Relationship between the insulin binding capacity of fat cells and the cellular response to insulin. Studies with intact and trypsin-treated fat cells. J. Biol. Chem. 246, 6210-6216 (1971)

20. Gliemann, J., Gammeltoft, S., Vinten, J.: Time course of insulin-receptor binding and insulin-induced lipogenesis in isolated rat fat cells. J. Biol. Chem. 250, 3368-3374 (1975)

21. Olefsky, J.M.: Effect of dexamethasone on insulin binding, glucose transport, and glucose oxidation of isolated rat adipocytes. J. Clin. Invest. 56, 1499-1508 (1975)

22. Le Marchand, Y., Jeanrenaud, B., Freychet, P.: Insulin binding and effects in the isolated soleus muscle of lean and obese mice. Am. J. Physiol. 234, 348-358 (1978)
23. Unger, R. H., Lefebvre, P. J.: Glucagon physiology. In: P. J. Lefebvre and R. H. Unger (eds.): Glucagon, molecular physiology, clinical and therapeutic implications, pp. 213-244. Oxford: Pergamon Press 1972

Received: November 28,1977

and in revised form: March 6, 1978

Dr. A. Le Cam

I.N.S.E.R.M

U. 145

Faculté de Médecine (Pasteur)

Chemin de Vallombrose

F-06034 Nice Cedex

France 